\title{
Differences Among Industrial Companies in Their Innovative Efforts and Competitiveness: On How Size, Technological Level and Subcontractor Character Matter
}

\author{
Ricardo Martínez Santa María, Jon Charterina Abando, Andrés Araujo de la Mata \\ University of the Basque Country, Bilbao, Spain
}

\begin{abstract}
The aim of this research is to test to what extent do the classifying variables of company size, technological level and subcontractor nature moderate on the causal relationship between a firm's innovative capacities and its competitiveness. To this end, we use a random sample of 861 manufacturing firms with 10 or more employees from the Basque Autonomous Community (in Spain), accounting for $26.29 \%$ of the population. Maximum sampling error is $2.87 \%$ for a $95 \%$ confidence interval. We start from a competitiveness general model of the firm, and set out under the resource based view of the firm, which had been previously tested and validated by Martinez (2009) for the whole sample. The model is formed with the constructs of management capabilities, innovative capabilities, marketing capabilities, quality capabilities, current competitiveness and future competitiveness. From this point, we test a set of alternative hierarchical models both for the total sample and for different divisions in sub-samples, according to the intervals of size in number of employees, OECD technological levels and firms' subcontractor character. The innovative capabilities construct is reflected in the items of radical product innovation, incremental product innovation, innovation in the production process, innovation in marketing, management innovation and the efforts in company workers' training and development. From all these items, previous descriptive data analysis showed that although product radical innovation was the most representative capability for superior innovativeness, it was at the same time the least evident from all the aforementioned items in the case of the analyzed Basque industrial companies. The analysis of results led us to conclude that the factor of innovative capabilities was the most influential on current competitiveness among the whole sample. In particular, as regards the size factor, this positive effect dilutes in the case of smaller companies. In the same manner, whereas in the case of the companies with higher technological level it is verified that the factor of innovative capabilities reveals crucial, in the group of firms with lower technological level the most relevant factor is quality. Also, the same effect is evidenced for the case of the subcontractor/non-subcontractor nature of the firms: The first ones show quality as the most relevant construct while for the second ones it is the innovative capabilities.
\end{abstract}

Keywords: competitiveness, innovative capabilities, company size, technological level, subcontractor character

Ricardo Martínez Santa María, Ph.D. in Business Economy, Vice-chancellorship of Research, University of the Basque Country. Jon Charterina Abando, Ph.D. in Business Economy, Department of Business Economy and Marketing, University of the Basque Country.

Andrés Araujo de la Mata, Ph.D. in Business Economy, Department of Business Economy and Marketing, University of the Basque Country. 


\section{Introduction}

Strategic management focuses mainly on identifying the factors that have more influence on competitiveness, as shown in the existing literature. The works that have studied the comparative effect of the internal firm's factors (firm effect), versus the external factors, conclude that the former is bigger than the latter (Rumelt, 1991; Roquebert, Phillips, \& Westfall, 1996; Mauri \& Michaels, 1998; Galán \& Vecino, 1997; Fernández, Montes, \& Vázquez, 1999; Claver, Molina, Quer, \& Tarí, 2005, etc.). Also, recent studies dealing with the firm effect, such as Martínez (2009), point out that, among the internal factors, innovation capabilities show the highest explanatory power on competitiveness in the case of industrial companies.

The main objective of our research is to delve into the study of the innovation effect (the effect of innovation capabilities on competitiveness, understanding them as an internal firm's factor) and to analyse how this effect is modulated by size, technological level and firm's subcontractor character variables.

To achieve this objective, we will use as starting point the explanatory model of competitiveness established in Martínez (2009), as well as its generic sample consisting of 861 Basque manufacturing companies. A series of hierarchical models of lower order based on it will be set out, and these models will be tested over different sub-samples depending on the aforementioned variables (smaller versus larger companies, lower technological level companies, higher technological level companies, subcontractor character companies and non-subcontractor character companies).

The original competitiveness model was established from the Resource Based View of the firm ${ }^{1}$ (Wernerfelt, 1984; Teece, 1986; Prahalad \& Hamel, 1990; Barney, 1991; Grant, 1991; Amit \& Schoemaker, 1993; Peteraf, 1993, etc.). Its measurement scales were identified in an empirical way by means of a fieldwork consisting of interviews with managers.

\section{An Explanatory Model of Competitiveness}

As it has been pointed out, the starting model is set out in Martínez (2009). This model, shown in Figure 1 (model 1), following the resource based view (RBV) establishes the relationship between four internal sources of competitiveness (management capabilities, innovation capabilities, marketing capabilities and quality capabilities) and the firm's performance, and in the same way, it poses management capabilities as a precedent of the other studied internal sources of competitiveness.

Every internal competitiveness factor in our study is conceptualized using the generic capability concept (O’Regan \& Ghobadian, 2004). The capabilities are the resources which help the most to reach the sustainable competitive advantage due to their complexity, higher tacit component, and specificity (Reed \& DeFillipi, 1990). The relationship between "unique capabilities", and performance is well established in the literature and has been researched from the different perspectives of the RBV (De Carolis, 2003, p. 35). However, all firms have more generic capabilities that enable them to compete. While unique capabilities are specific of firms in particular competitive positions, generic capabilities are present in most firms and have a positive association with both strategy and overall organizational performance (O'Regan \& Ghobadian, 2004, p. 293). Therefore, the concept of

\footnotetext{
1 In the following RBV.

2 Regarded as nuclear (Prahalad \& Hamel, 1990), or distinctive (Selznick, 1957).
} 
generic capability presents a wider applicability than those of nuclear capability or distinctive capability. That is, since generic capabilities are not unique of a particular company, their research does not involve a deep analysis of every firm; on the contrary, it can be carried out using a firm's sample, as occurs in our case.

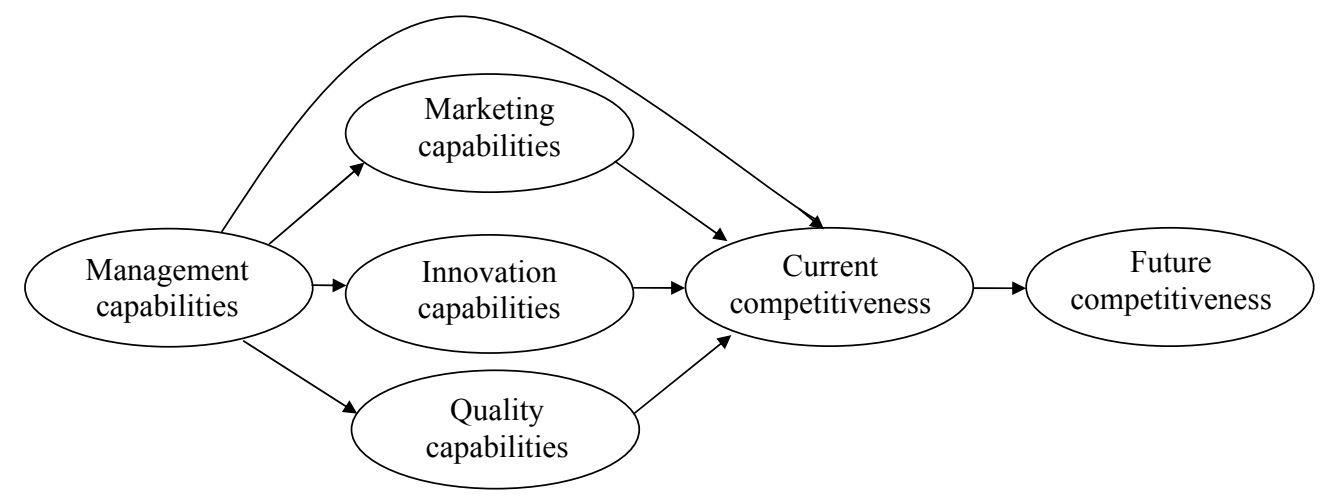

(a) Model 1

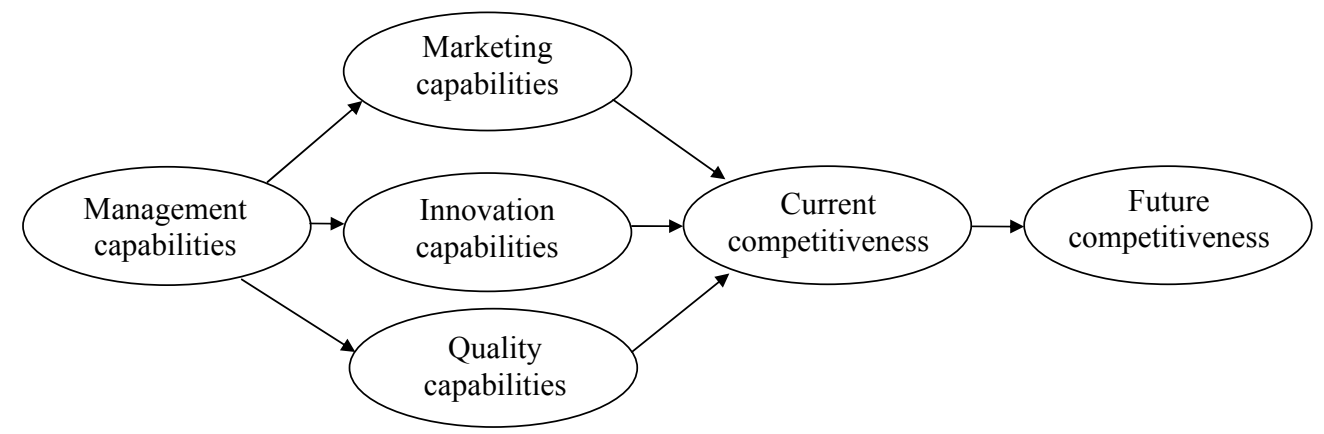

(b) Model 2

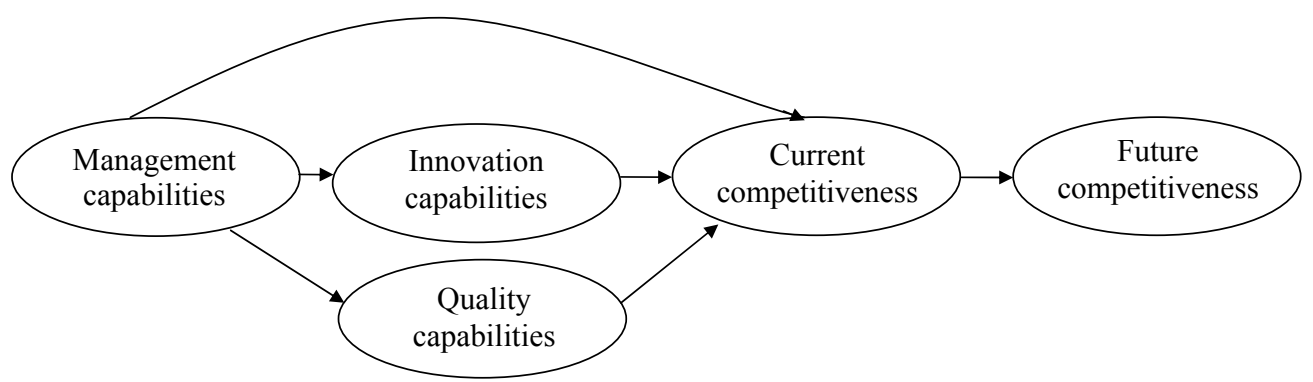

(c) Model 3

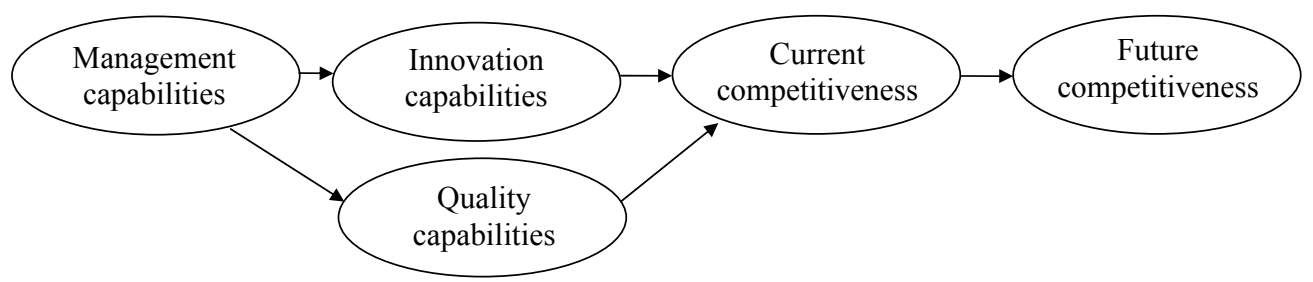

(d) Model 4

(to be continued) 


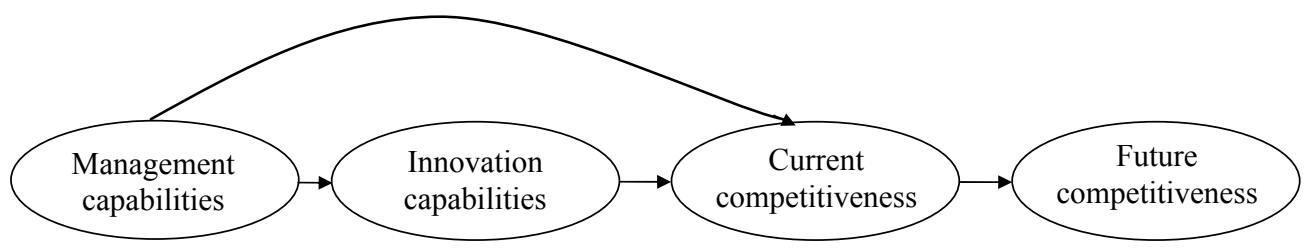

(e) Model 5

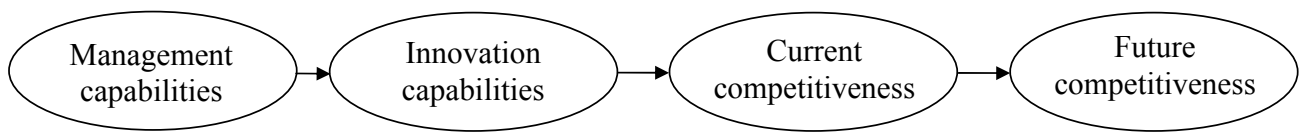

(f) Model 6

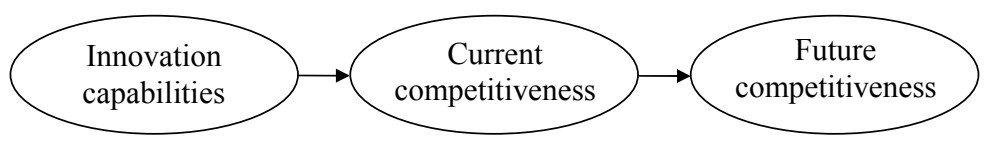

(g) Model 7

Figure 1. Compared hierarchical models.

Table 1 shows some of the works that back every established relationship up in a theoretical way, as well as the works that find empirical evidence of it.

Table 1

Studies That Support the Relationships Established in the Model

\begin{tabular}{|c|c|c|}
\hline Causal relationship & Theoretical support & Empirical evidence \\
\hline $\begin{array}{l}\text { Management capabilities- } \\
\text { Competitiveness }\end{array}$ & $\begin{array}{l}\text { Castanias and Helfat (1991, 2001), Mahoney and } \\
\text { Pandian (1992), Lado and Wilson (1994), } \\
\text { Mahoney (1995), etc.. }\end{array}$ & $\begin{array}{l}\text { Carmeli (2001), Lerner and Almor (2002), } \\
\text { Acquaah (2003), Kor (2003), Carmeli and Tishler } \\
\text { (2006), etc.. }\end{array}$ \\
\hline $\begin{array}{l}\text { Innovation capabilities- } \\
\text { Competitiveness }\end{array}$ & See the following section. & See the following section. \\
\hline $\begin{array}{l}\text { Marketing capabilities- } \\
\text { Competitiveness }\end{array}$ & $\begin{array}{l}\text { Webster (1992), Day (1994), Hooley, Broderick } \\
\text { and Möller (1998), Srivastava, Fahey, Christensen } \\
\text { (2001), Fahy and Smithee (1999), etc.. }\end{array}$ & $\begin{array}{l}\text { Hunt and Morgan (1995), Dutta et al. (1999), } \\
\text { Hooley et al. (1999, 2005), Milfelner et al. (2008), } \\
\text { etc.. }\end{array}$ \\
\hline $\begin{array}{l}\text { Quality capabilities- } \\
\text { Competitiveness }\end{array}$ & $\begin{array}{l}\text { Hall (1992), Lado and Wilson (1994), Zollo and } \\
\text { Winter (2002), Perdomo-Ortiz, González-Benito } \\
\text { and Galende (2006), etc.. }\end{array}$ & $\begin{array}{l}\text { Powell (1995), Hooley, Fahy, Cox, Beracs, } \\
\text { Fonfara and Snoj (1999), Calvo and López (2003), } \\
\text { Lee (2004), Rubio and Aragón (2008), etc.. }\end{array}$ \\
\hline $\begin{array}{l}\text { Management capabilities- } \\
\text { Innovation capabilities }\end{array}$ & $\begin{array}{l}\text { Forrest (1991), Rothwell (1994), Pavitt (2003), } \\
\text { Perdomo et al. (2006), etc.. }\end{array}$ & $\begin{array}{l}\text { Galende and Suárez (1998, 1999), Martínez-Ros } \\
\text { and Salas (1999), etc.. }\end{array}$ \\
\hline $\begin{array}{l}\text { Management capabilities- } \\
\text { Marketing capabilities }\end{array}$ & $\begin{array}{l}\text { Jaworski and Kohli (1993), Day (1994), Spillan } \\
\text { and Ziemnowicz (2003), Acquaah (2003), etc.. }\end{array}$ & $\begin{array}{l}\text { Weigelt and Camerer (1998), Calvo and López } \\
(2003) \text {, Hooley, Greenley, Cadogan and Fahy } \\
(2005) \text {, etc.. }\end{array}$ \\
\hline $\begin{array}{l}\text { Management capabilities- } \\
\text { Quality capabilities }\end{array}$ & $\begin{array}{l}\text { Juran (1990), Powell (1995), Parasuraman, } \\
\text { Zeithaml and Berry (1985), etc.. }\end{array}$ & Acquaah (2003), Perdomo et al. (2006), etc.. \\
\hline
\end{tabular}

\section{Innovation Capabilities}

\section{Innovation Capabilities and Firm's Performance}

There seems to be consensus, both in the academic and in the business spheres, which one of the firm's main resources is its technological knowledge, together with its capability to generate innovations (Galende, 2006). The technological factor and the capability to innovate have become a critical source of competitive advantage (Galende \& Suárez, 1999).

In spite of the dramatic increase in the literature addressing the role and nature of innovation, a widely-held consensus regarding how to define innovation has not been yielded yet. Innovation concept is complex and 
blurred; however, a common denominator underlies all its definitions: the newness concept (Johannessen, Olsen, \& Lumpkin, 2001). The Oslo Manual defines innovation as "the implementation of a new or significantly improved product (good or service), or process, a new marketing method, or a new organisational method in business practices, workplace organisation or external relations".

The RVB emphasizes the importance of innovation as a source of competitive advantage (Hall, 1993; Carmeli, 2001). Prahalad and Hamel (1990, p. 82) point out that, in the long term, competitiveness derives from the possibility of creating technologies and essential skills be able to produce absolutely innovator products, at lower cost and a greater pace than the competitors. Likewise, the RBV is the most suitable perspective to analyse the mutual effect of other intangible resources (of human, commercial or organizational type) on innovative activities (Galende \& Suárez, 1999) and to analyse the innovation process from the internal perspective (Leornard-Barton, 1992).

Table 2

Factor Loadings for Each Item From the Measurement Model, Factor Correlations and General Goodness of Fit From the Model

\begin{tabular}{|c|c|c|c|c|c|c|c|}
\hline \multicolumn{2}{|r|}{ Factors } & \multicolumn{2}{|r|}{ Variables } & \multirow{2}{*}{$\begin{array}{c}\text { Loading } \\
0.693\end{array}$} & \multicolumn{2}{|c|}{ Factors } & Correlation \\
\hline \multirow{3}{*}{$\mathrm{F}_{1}$} & \multirow{3}{*}{$\begin{array}{l}\text { Marketing } \\
\text { capabilities } \\
\left(\alpha_{\text {Cronbach }}=0.671\right)\end{array}$} & $\mathrm{P}_{1}$ & Company reputation & & $\mathrm{F}_{1}$ & $\mathrm{~F}_{2}$ & 0.746 \\
\hline & & $\mathrm{P}_{5}$ & $\begin{array}{l}\text { Market surveillance: knowledge from customers and } \\
\text { competitors }\end{array}$ & 0.691 & $\mathrm{~F}_{1}$ & $\mathrm{~F}_{4}$ & 0.330 \\
\hline & & $\mathrm{P}_{2}$ & Marketing effort & 0.651 & $\mathrm{~F}_{1}$ & $\mathrm{~F}_{8}$ & 0.508 \\
\hline \multirow{4}{*}{$\mathrm{F}_{2}$} & \multirow{4}{*}{$\begin{array}{l}\text { Management } \\
\text { capabilities } \\
\left(\alpha_{\text {Cronbach }}=0.768\right)\end{array}$} & $\mathrm{P}_{7}$ & Qualification of managers & 0.753 & $\mathrm{~F}_{1}$ & $\mathrm{~F}_{9}$ & 0.221 \\
\hline & & $\mathrm{P}_{6}$ & Managers' strategic vision & 0.687 & $\mathrm{~F}_{1}$ & $\mathrm{~F}_{10}$ & 0.180 \\
\hline & & $\mathrm{P}_{9}$ & Innovation in administration and management & 0.579 & $\mathrm{~F}_{2}$ & $\mathrm{~F}_{4}$ & 0.394 \\
\hline & & $\mathrm{P}_{8}$ & Investment in employees' training and development & 0.560 & $\mathrm{~F}_{2}$ & $\mathrm{~F}_{8}$ & 0.520 \\
\hline \multirow{5}{*}{$\mathrm{F}_{4}$} & \multirow{5}{*}{$\begin{array}{l}\text { Innovation } \\
\text { capabilities } \\
\left(\alpha_{\text {Cronbach }}=0.822\right)\end{array}$} & $\mathrm{P}_{16}$ & Radical product innovation & 0.849 & $\mathrm{~F}_{2}$ & $\mathrm{~F}_{9}$ & 0.255 \\
\hline & & $\mathrm{P}_{15}$ & Incremental product innovation & 0.818 & $\mathrm{~F}_{2}$ & $\mathrm{~F}_{10}$ & 0.239 \\
\hline & & $\mathrm{P}_{17}$ & Innovation in production and commercial processes & 0.785 & $\mathrm{~F}_{4}$ & $\mathrm{~F}_{8}$ & 0.406 \\
\hline & & $\mathrm{P}_{9}$ & Innovation in administration and management & 0.373 & $\mathrm{~F}_{4}$ & $\mathrm{~F}_{9}$ & 0.300 \\
\hline & & $\mathrm{P}_{8}$ & Investment in employees' training and development & 0.265 & $\mathrm{~F}_{4}$ & $\mathrm{~F}_{10}$ & 0.340 \\
\hline \multirow{2}{*}{$\mathrm{F}_{8}$} & \multirow{2}{*}{\begin{tabular}{|l|} 
Quality \\
capabilities \\
$\left(\alpha_{\text {Cronbach }}=0.695\right)$ \\
\cline { 2 - 2 }
\end{tabular}} & $\mathrm{P}_{41}$ & Product subjective quality (reputation of product) & 0.869 & $\mathrm{~F}_{8}$ & $\mathrm{~F}_{9}$ & 0.239 \\
\hline & & $\mathrm{P}_{40}$ & Product objective quality & 0.700 & $\mathrm{~F}_{8}$ & $\mathrm{~F}_{10}$ & 0.281 \\
\hline \multirow{2}{*}{$\mathrm{F}_{9}$} & \multirow{2}{*}{$\begin{array}{l}\text { Current } \\
\text { competitiveness } \\
\left(\alpha_{\text {Cronbach }}=0.719\right)\end{array}$} & $\mathrm{P}_{43}$ & $\begin{array}{l}\text { Increase of sales during the last three years with respect } \\
\text { to the competitors of reference }\end{array}$ & 0.823 & $\mathrm{~F}_{9}$ & $\mathrm{~F}_{10}$ & 0.517 \\
\hline & & $\mathrm{P}_{44}$ & $\begin{array}{l}\text { Profitability during the last three years with respect to } \\
\text { the competitors of reference }\end{array}$ & 0.738 & \multicolumn{3}{|c|}{ Model fit } \\
\hline \multirow{2}{*}{$\mathrm{F}_{10}$} & \multirow{2}{*}{$\begin{array}{l}\text { Future } \\
\text { competitiveness } \\
\left(\alpha_{\text {Cronbach }}=0.728\right)\end{array}$} & $\mathrm{P}_{48}$ & $\begin{array}{l}\text { Profitability for the next three years with respect to the } \\
\text { competitors of reference }\end{array}$ & 0.836 & \multirow{2}{*}{\multicolumn{3}{|c|}{$\begin{array}{l}\text { NFI: } 0.949 \\
\text { CFI: } 0.969 \\
\text { RMSEA: } 0.041 \\
\text { RMSEA }_{90 \%}: 0.034-0.048 \\
\end{array}$}} \\
\hline & & $\mathrm{P}_{47}$ & $\begin{array}{l}\text { Sales increase for the next three years with respect to the } \\
\text { competitors of reference }\end{array}$ & 0.812 & & & \\
\hline
\end{tabular}

Tether (2003) shows that the innovation capability is linked with an attitude and a set of practices and behaviours related to this attitude. Under this notion, innovation is a dynamic capability (Zollo \& Winter, 2002, p. 340). In the same way, Perdomo et al. (2006) considered the innovation capability of a firm as a wide and multi-dimensional concept enhancing several aspects of the firm (i.e., planning and commitment on the part of management, behaviour and integration, projects, knowledge and skills, information and communication and external environment). 
In the case of manufacturing firms, there is a wealth of evidence in academic literature that shows a positive relationship between innovation and the firm's overall performance among the most recent (Kafouros, 2008). The equivalent studies about service firms are less frequent, although there exists empirical evidence of a positive relationship too (e.g., Cainelli, Evangelista, \& Savona, 2006). The Oslo Manual (OECD, 2005) also makes it clear the link between a firm's innovation and its performance: "It is crucial to know why firms innovate. The ultimate reason is to improve firm performance, for example by increasing demand or reducing costs" (paragraph 77).

The previous arguments lead us to formulate the following hypothesis:

$\mathrm{H}_{1}$ : Those firms with better innovation capabilities reach better performance.

Table 2 shows the variables used for measuring the innovation capability of the firm. Like for the rest of the factors under study, a subjective with 5 item-Likert scale has been used. This scale resulted from a previous empirical fieldwork consisting of in-depth interviews with managers, and is theoretically supported by the Oslo Manual (OECD, 2005) "Guidelines for collecting and interpreting innovation data".

\section{Relationship Between Innovation Capabilities and Size, Technological Level and Subcontractor Character of the Firm}

Returns on innovation depend on the firm's ability to develop technological innovations, but also may depend on the ability to exploit and appropriate the returns on technological developments (Griliches, 1979), as well as on its ability to implement strategies that lead the firm to get economic benefit from innovation.

Trying to explain the variation in the returns on innovation, many scholars have argued that because technologically sophisticated firms participate in sectors where the understanding and the scientific knowledge related to innovation is rich and growing, and their innovative efforts significantly influence their performance (Clark \& Griliches, 1984). Empirical findings have supported these propositions, indicating that the returns on innovation tend to be very positive for high-tech firms (Griliches \& Mairesse, 1984; Wang \& Tsai, 2003).

Other scholars have suggested that various factors such as economies of scale and scope, technical expertise and managerial qualities allow large firms to enjoy high returns on innovation (Mansfield, 1968). However, the empirical findings concerning the role of firm size are inconclusive. Some studies indicate that the effects of innovation depend on firm size (Lichtenberg \& Siegel, 1991; Cohen \& Klepper, 1996), whereas others found no evidence of such an association (Griliches, 1980; Wang \& Tsai, 2003).

Other authors, such as Kafouros (2008), consider that along with size and technological opportunities of the sector, the internationalization degree of the firm also moderates the innovation capability-performance relationship. The internationalization factor is out of scope of our study, but nevertheless, due to the positive relationship showed between internationalization and size (Aguirre, Charterina, Idigoras, Martinez, \& Matey, 2006, p. 171), this factor could be considered to a certain extent implicit in the size factor.

In our study, as well as the moderating effects of firm size and technological level on the innovation capabilities-performance relationship, we want to test the differences in the innovation effect between subcontractor firms (those which manufacture under the request of their clients, in the majority of the cases without any decision capacity about the design or the technical characteristics of the product) and the non-subcontractor firms. Our interest in this issue is due to the relatively higher presence of subcontractor firms within the Basque industry compared to the rest of Spain. In fact, around $50 \%$ of the Basque manufacturers regard 
themselves as subcontractors in a higher or lower degree (Martínez, 2009, pp. 231, 307). Then, there seems logical to pose that in the case of the subcontractor firms, because of the lower decision capacity on the product, the relationship between innovation capabilities and performance (innovation effect) is lower.

The previous arguments lead us to formulate the following hypotheses:

$\mathrm{H}_{2}$ : The innovation effect is moderated by the size of the firm, being higher for the bigger firms.

$\mathrm{H}_{3}$ : The innovation effect is moderated by the technological level of the firm, being higher for the firms with higher technological level.

$\mathrm{H}_{4}$ : The innovation effect is moderated by the subcontractor character of the firm, being higher for the non-subcontractor firms.

\section{Characteristics of the Empirical Research}

The empirical research consisted of two parts. The first part, of a qualitative and exploratory nature, had a main objective to determine the variables that characterise the internal factors included in our study (management capabilities, innovation capabilities, marketing capabilities and quality capabilities). The second part of the research carried out a statistical analysis in order to contrast the aforementioned hypotheses. Proceeding in this way means to follow the research maturity cycle, according to Malhotra and Grover (1998). On the other hand, the joint use of qualitative and quantitative methods in the same study is called methodological triangulation (Denzin, 1970). To be precise, following the mixed method classification by Creswell (1995), our study can be considered a two-phased sequential study of equivalent status.

During the qualitative phase, the technique of information collection used was interviews with managers, being these managers chosen by means of a reputational sampling (Human \& Provan, 1997). Once the interviews were analysed, a series of focus groups were carried out within the research team in order to reduce the number of variables featuring each factor, taking into account that the measuring instrument to be used in the quantitative phase (questionnaire) must be as reduced as possible in order to make it operative. Table 2 shows the scales finally used to measure the studied factors, all of them consisting of 5 point-Likert items.

The field-work carried out on the second phase consisted of a telephone interview to managers of 861 Basque manufacturing companies ${ }^{3}$ with 10 or more employees, which account for the $26.29 \%$ of such a population ${ }^{4}$. The committed random error is lower than $2.87 \%$ (for a confidence interval of $95 \%$ ). The survey was carried out from April 24, 2006 to May 10.

The statistical technique used for testing the hypotheses was by means of Structural Equation Modelling.

\section{Analysis and Results}

The hypothesis test was performed using hierarchical structural equation factorial models, all of which share a same measurement model, which is showed in Table 2. More specifically, the measurement model results are showed after the corresponding reliability (Cronbach's alpha) and validity tests.

\footnotetext{
${ }^{3}$ The manufacturing industry accounts for the $98.09 \%$ of the employment and the $88.66 \%$ of the gross value added (GVA) of the whole Basque industry (Eustat, 2008).

${ }^{4}$ The sampling frame, consisting of 3,275 firms, was obtained from the Bureau van Dick's SABI data base (February 2006 release).
} 
As it can be seen, the measurement model gives good convergent validity results, judging by the fact that all the specific factor measurement indicators show good convergent validity results. All of the standardized factor loadings are relatively high (greater than 0.600 , according to Marsh \& Hau, 1999) ${ }^{5}$. Also, it shows good discriminant validity results, as it is shown by the fact that correlations among the factors are not excessively high (no greater than 0.850 , according to Kline, 2005, p. 73) ${ }^{6}$. Also, the general adjustment of the measurement model is optimum ${ }^{7}$.

From this initial measurement model, we analyse a series of hierarchical causal models, illustrated in Figure 1. All of them are derived from model 1 (tested by Martínez, 2009). Hierarchical models that are simpler than them (model 2 to model 7) are formed by means of suppressing one of the given causal relations proposed, or some of the factors, and keeping the innovation and competitiveness capabilities as a core ${ }^{8}$.

This proceeding manner of forming and testing different hierarchical models follows a recommendation for the use of structural equation modelling (Kline, 2005, p. 64) ${ }^{9}$.

Table 3 shows the testing results for the 7 models considering the whole sample (described in section 4 ).

Table 3

Results of the Structural Equation Modelling for the General Sample

\begin{tabular}{|c|c|c|c|c|c|c|c|c|c|c|c|c|}
\hline Model & NFI & Factor & & $\begin{array}{l}\text { Marketing } \\
\text { capabilities }\end{array}$ & & $\begin{array}{l}\text { Innovation } \\
\text { capabilities }\end{array}$ & & $\begin{array}{l}\text { Quality } \\
\text { capabilities }\end{array}$ & & $\begin{array}{l}\text { Management } \\
\text { capabilities }\end{array}$ & & \\
\hline Model 1 & 0.939 & $\mathrm{~F}_{9}$ & $=$ & $\begin{array}{l}0.027 * \mathrm{~F}_{1} \\
(0.205)\end{array}$ & + & $\begin{array}{c}0.224 * F_{4} \\
(4.017 @)\end{array}$ & + & $\begin{array}{l}0.123 * \mathrm{~F}_{8} \\
(1.676)\end{array}$ & + & $\begin{array}{l}0.087 * \mathrm{~F}_{2} \\
(0.802)\end{array}$ & + & $\mathrm{D}_{9}$ \\
\hline Model 2 & 0.939 & $\mathrm{~F}_{9}$ & $=$ & $\begin{array}{l}0.118 * \mathrm{~F}_{1} \\
(1.664)\end{array}$ & + & $\begin{array}{c}0.241 * F_{4} \\
(4.987 @)\end{array}$ & + & $\begin{array}{c}0.148 * \mathrm{~F}_{8} \\
(2.469 @)\end{array}$ & & & + & $\mathrm{D}_{9}$ \\
\hline Model 3 & 0.948 & $\mathrm{~F}_{9}$ & $=$ & & & $\begin{array}{c}0.213^{*} \mathbf{F}_{4} \\
(3.781 @)\end{array}$ & + & $\begin{array}{l}0.131 * \mathrm{~F}_{8} \\
(1.875)\end{array}$ & + & $\begin{array}{l}0.106 * \mathrm{~F}_{2} \\
(1.727)\end{array}$ & + & $\mathrm{D}_{9}$ \\
\hline Model 4 & 0.947 & $\mathrm{~F}_{9}$ & $=$ & & & $\begin{array}{c}0.256 * F_{4} \\
(5.891 @)\end{array}$ & + & $\begin{array}{c}0.209 * \mathrm{~F}_{8} \\
(4.031 @)\end{array}$ & & & + & $\mathrm{D}_{9}$ \\
\hline Model 5 & 0.953 & $\mathrm{~F}_{9}$ & $=$ & & & $\begin{array}{c}0.240 * F_{4} \\
(4.421 @)\end{array}$ & & & + & $\begin{array}{c}0.152 * \mathrm{~F}_{2} \\
(3.342 @)\end{array}$ & + & $\mathrm{D}_{9}$ \\
\hline Model 6 & 0.950 & $\mathrm{~F}_{9}$ & $=$ & & & $\begin{array}{c}0.336 * F_{4} \\
(7.488 @)\end{array}$ & & & & & + & $\mathrm{D}_{9}$ \\
\hline Model 7 & 0.954 & $\mathrm{~F}_{9}$ & $=$ & & & $\begin{array}{c}0.272 * \mathbf{F}_{4} \\
(7.524 @)\end{array}$ & & & & & + & $\mathrm{D}_{9}$ \\
\hline
\end{tabular}

Note. The highest value for each case is in bold letters.

\footnotetext{
${ }^{5}$ In the case of items $P_{8}$ and $P_{9}$, which charge on two factors, we would use as validity indicator the fact that the coefficient of the error term is less than 0.800 (value corresponding to a single factor loading of 0.600 ). The error coefficients for $P_{8}$ and $P_{9}$ are 0.706 and 0.596, respectively. Therefore, the model follows Marsh and Hau's rule (1999).

${ }^{6}$ As it can be seen, the highest estimation for a correlation between factors $\left(F_{l}-F_{2}\right)$ is 0.746 , less than 0.850 .

7 Originally, for a model it was considered a good fit obtaining NFI (Bentler-Bonett normed fit index, Bentler \& Bonett, 1980) and CFI (Comparative fit index, Bentler, 1990) values higher than 0.900 (Bentler, 1992). However, more recently it was recommended to reach a value of 0.950 ( $\mathrm{Hu} \&$ Bentler, 1999). As regards the RMSEA (Steiger-lind root mean square error of approximation, Steiger \& Lind, 1980), values lower than 0.050 indicate a good fit, and values of up to 0.080 represent a reasonable approximation of error (Browne \& Cudeck, 1993), with the lower limit value of the confidence interval at $90 \%$ (Steiger, 1990) below 0.050, and an upper limit not too much over 0.050 (Kline, 2005, p. 139).

${ }^{8}$ In the case of model 7, starting from model 6, apart from the decision of eliminating the management capabilities factor, it is allowed for the error from $P_{8}$ to covariate with the error from $P_{9}$, following the recommendation of the Lagrange test of multivariate multiplicator. This decision brings a considerable reduction of the $\chi^{2}$ value of the model, and thus a good increase of its general fit.

${ }_{9}$ Despite it, studies such as MacCallum et al. (1993) or MacCallum and Austin (2000), which analyze articles that use this technique (SEM) in scientific literature, show that researchers are reluctant to fulfill this commitment.
} 
As shown in Table 3, for the case of all the models the direct effect from innovation on competitiveness (i.e., the innovation effect) ${ }^{10}$ is positive, significant and the greatest one in absolute terms. Therefore, this confirms $\mathrm{H}_{1}$.

Though not formally hypothesized, it is worth mentioning that quality capabilities, in model 2 and model 4, do exert a significant positive influence moderating management capabilities, over present competitiveness. Exactly, this happens when there is no direct effect from the former over the latter. In consequence, it is an evidence of the mediating effect from quality capabilities with respect to management capabilities.

Next, the 7 models are tested with 6 different sub-samples, enabling us to determine to which extent the relationship between the innovation capabilities and competitiveness is influenced by company size, its technological level, and its subcontractor character.

Table 4 shows the characteristics of the general sample and the sub-samples used.

Table 4

Descriptive Information From the Sub-samples

\begin{tabular}{lll}
\hline Sample & No. of firms & Percent of the general sample \\
\hline Firms with size smaller or equal to the median $^{\mathrm{a}}$ & 437 & $50.75 \%$ \\
Firms with size bigger than the median & 424 & $49.25 \%$ \\
Firms with OECD technological level low or medium-low & 586 & $68.06 \%$ \\
Firms with OECD technological level medium-high or high & 275 & $31.94 \%$ \\
Subcontractor firms & 425 & $49.36 \%$ \\
Non-subcontractor firm & 418 & $48.55 \%$ \\
General sample & 861 & $100 \%$ \\
\hline
\end{tabular}

Notes. ${ }^{a}$ The median value from the sample is 36 employees; ${ }^{b}$ For the case of the sample partitions according to the subcontractor character, the sum from both sub-samples does not form a complete sample, as there were 18 missing cases (Don't know/Don't answer).

Table 5, Table 6 and Table 7 show the contrast results for these sub-samples. Each model presents its NFI (Bentler-Bonett normed fit index, Bentler \& Bonett, 1980) ${ }^{11}$ general goodness of fit value. The factorial regression function showed in all cases is the corresponding for factor $F_{9}$ (current competitiveness) ${ }^{12}$, with non-standardized coefficients of the direct effects among the factors, as well as the $z$ robust coefficient ${ }^{13}$ (in parenthesis).

In Table 5, if we compare the effect from innovation capabilities to any of the other considered (internal) effects on competitiveness, we could conclude that the explaining power from the innovation capabilities on competitiveness increases along with company size, which confirms $\mathrm{H}_{2}$. In fact, in all the models, the most determinant factor of competitiveness for the larger size-group is the innovation capabilities factor. However, for the case of the smaller firms, despite the importance of the innovation effect, the most important effect is the

\footnotetext{
${ }^{10}$ We call innovation effect to the effect from the innovation capabilities on competitiveness, and correspondingly, quality effect to the effect from the quality capabilities, management effect to the effect from the management capabilities, and marketing effect to the effect from the marketing capabilities.

${ }_{11}$ We show the NFI and not the CFI (Comparative fit index, Bentler, 1990) values, because NFI values are lower in all cases, and thus, more restrictive. As it can be seen, in all cases this value is higher than 0.900, indicating a good general fit (Bentler, 1992).

${ }_{12}$ Only the structural equation corresponding to $F_{9}$ is represented, as the rest of relationships that were devised for the rest of the models, showed values that were positive and significant at an alpha level of $5 \%$.

${ }^{13}$ The $z$ coefficient is determined dividing the value from the direct effect into the estimated robust standard error (SE). The @ symbol indicates significance lower than $5 \%$.
} 
quality capabilities factor ${ }^{14}$. It seems that as companies grow in size the advantages from the quality dilute in favour of the innovation capabilities, and to a lesser degree in favour of the management and marketing capabilities $^{15}$. These results seem to agree with the empirical evidence that relates company size with the establishment of quality management systems. For example, it has been evidenced that middle sized and large companies tend to succeed more than the smaller ones in the application of the ISO 9000 system (Climent, 2004). These results seem to show that the quality issue loses relevance as an antecedent of competitiveness for larger companies, compared to SMEs (small and mid-sized) companies, where differences do exist.

Table 5

Results From the Structural Model According to the Company Size

\begin{tabular}{|c|c|c|c|c|c|c|c|c|c|c|c|c|c|}
\hline Model & Size & NFI & Comp & & $\begin{array}{l}\text { Marketing } \\
\text { capabilities }\end{array}$ & & $\begin{array}{l}\text { Innovation } \\
\text { capabilities }\end{array}$ & & $\begin{array}{l}\text { Quality } \\
\text { capabilities }\end{array}$ & & $\begin{array}{l}\text { Managing } \\
\text { capabilities }\end{array}$ & & \\
\hline Model 1 & $<=$ median & 0.915 & $\mathrm{~F}_{9}$ & $=$ & $\begin{array}{l}-0.094 * \mathrm{~F} 1 \\
(-0.379)\end{array}$ & + & $\begin{array}{c}0.212 * \mathrm{~F}_{4} \\
(2.990 @)\end{array}$ & + & $\begin{array}{c}0.258 * F_{8} \\
(2.290 @)\end{array}$ & + & $\begin{array}{l}0.058 * F_{2} \\
(0.338)\end{array}$ & + & $\mathrm{D}_{9}$ \\
\hline Model 1 & $>$ median & 0.915 & $\mathrm{~F}_{9}$ & $=$ & $\begin{array}{l}0.045^{*} \mathrm{~F} 1 \\
(0.313)\end{array}$ & + & $\begin{array}{l}0.163 * F_{4} \\
(1.889)\end{array}$ & + & $\begin{array}{l}0.075 * \mathrm{~F}_{8} \\
(0.737)\end{array}$ & + & $\begin{array}{l}0.099 * \mathrm{~F}_{2} \\
(0.702)\end{array}$ & + & $\mathrm{D}_{9}$ \\
\hline Model 2 & $<=$ median & 0.915 & $\mathrm{~F}_{9}$ & $=$ & $\begin{array}{l}-0.022 * \mathrm{~F} 1 \\
(-0.172)\end{array}$ & + & $\begin{array}{c}0.222 * \mathrm{~F}_{4} \\
(3.436 @)\end{array}$ & + & $\begin{array}{c}0.277 * \mathbf{F}_{8} \\
(3.054 @)\end{array}$ & & & + & $\mathrm{D}_{9}$ \\
\hline Model 2 & $>$ median & 0.915 & $\mathrm{~F}_{9}$ & $=$ & $\begin{array}{l}0.137 * \mathrm{~F} 1 \\
(1.626)\end{array}$ & + & $\begin{array}{c}0.182 * F_{4} \\
(2.548 @)\end{array}$ & + & $\begin{array}{l}0.104 * \mathrm{~F}_{8} \\
(1.286)\end{array}$ & & & + & $\mathrm{D}_{9}$ \\
\hline Model 3 & $<=$ median & 0.931 & $\mathrm{~F}_{9}$ & $=$ & & & $\begin{array}{c}0.210 * \mathrm{~F}_{4} \\
(2.905 @)\end{array}$ & + & $\begin{array}{c}0.257 * F_{8} \\
(2.447 @)\end{array}$ & + & $\begin{array}{l}0.017 * \mathrm{~F}_{2} \\
(0.193)\end{array}$ & + & $\mathrm{D}_{9}$ \\
\hline Model 3 & $>$ median & 0.925 & $\mathrm{~F}_{9}$ & $=$ & & & $\begin{array}{l}0.151 * F_{4} \\
(1.733)\end{array}$ & + & $\begin{array}{l}0.079 * \mathrm{~F}_{8} \\
(0.787)\end{array}$ & + & $\begin{array}{l}0.136 * \mathrm{~F}_{2} \\
(1.529)\end{array}$ & + & $\mathrm{D}_{9}$ \\
\hline Model 4 & $<=$ median & 0.930 & $\mathrm{~F}_{9}$ & $=$ & & & $\begin{array}{c}0.216 * \mathrm{~F}_{4} \\
(3.679 @)\end{array}$ & + & $\begin{array}{c}0.271 * F_{8} \\
(3.746 @)\end{array}$ & & & + & $\mathrm{D}_{9}$ \\
\hline Model 4 & $>$ median & 0.923 & $\mathrm{~F}_{9}$ & $=$ & & & $\begin{array}{c}0.214 * F_{4} \\
(3.319 @)\end{array}$ & + & $\begin{array}{c}0.167 * \mathrm{~F}_{8} \\
(2.300 @)\end{array}$ & & & + & $\mathrm{D}_{9}$ \\
\hline Model 5 & $<=$ median & 0.933 & $\mathrm{~F}_{9}$ & $=$ & & & $\begin{array}{c}0.208 * F_{4} \\
(3.012 @)\end{array}$ & & & + & $\begin{array}{c}0.129 * \mathrm{~F}_{2} \\
(2.161 @)\end{array}$ & + & $\mathrm{D}_{9}$ \\
\hline Model 5 & $>$ median & 0.944 & $\mathrm{~F}_{9}$ & $=$ & & & $\begin{array}{c}0.196 * F_{4} \\
(2.439 @)\end{array}$ & & & + & $\begin{array}{c}0.147 * \mathrm{~F}_{2} \\
(2.280 @)\end{array}$ & + & $\mathrm{D}_{9}$ \\
\hline Model 6 & $<=$ median & 0.931 & $\mathrm{~F}_{9}$ & $=$ & & & $\begin{array}{c}0.272 * F_{4} \\
(4.581 @)\end{array}$ & & & & & + & $\mathrm{D}_{9}$ \\
\hline Model 6 & $>$ median & 0.941 & $\mathrm{~F}_{9}$ & $=$ & & & $\begin{array}{c}0.288 * F_{4} \\
(4.306 @)\end{array}$ & & & & & + & $\mathrm{D}_{9}$ \\
\hline Model 7 & $<=$ median & 0.937 & $\mathrm{~F}_{9}$ & $=$ & & & $\begin{array}{c}0.221 * F_{4} \\
(4.565 @)\end{array}$ & & & & & + & $\mathrm{D}_{9}$ \\
\hline Model 7 & $>$ median & 0.948 & $\mathrm{~F}_{9}$ & $=$ & & & $\begin{array}{c}0.227 * F_{4} \\
(4.268 @)\end{array}$ & & & & & & \\
\hline
\end{tabular}

Note. The highest value for each case is in bold letters.

However, the analysis of the current literature does not seem to show unanimously whether company size represents a help or an obstacle over innovativeness or over innovation capabilities. On the one hand, there is

\footnotetext{
${ }^{14}$ Although the effect from the quality factor is greater than that from the innovation factor, for the case of the smaller companies group the innovation effect results significant for an alpha of less than $5 \%$ in all cases, except for model 1 for which significance level is around $6 \%$.

15 Nevertheless, the effects from management and marketing are not significant for the majority of the cases.
} 
theoretical evidence pointing to the fact that a smaller size favours flexibility in comparison to larger and vertically integrated companies (Piore \& Sabel, 1984). On the other hand, there is empirical evidence backing the idea that SMEs tend to be more dynamic in product innovations (Acs \& Audretsch, 1990). Contrary to this, there is research showing that bigger enterprises have a bigger internal knowledge-base (Cohen \& Levinthal 1990), as well as the benefits from economies of scale, or the availability of financing that allows them to invest on innovation projects (Huergo \& Jaumandreu, 2004; Cefis \& Marsili, 2005). In this sense, the evidence that seems to come up from the results here obtained is that larger companies can develop more easily internal innovative capabilities in order to obtain competitive advantage.

Table 6

Results From the Structural Model According to the OECD Technological Level

\begin{tabular}{|c|c|c|c|c|c|c|c|c|c|}
\hline Model & OECD level & NFI & Comp & $\begin{array}{l}\text { Marketing } \\
\text { capabilits }\end{array}$ & $\begin{array}{l}\text { Innovation } \\
\text { capabilitis }\end{array}$ & & $\begin{array}{l}\text { Quality } \\
\text { capabilitis }\end{array}$ & $\begin{array}{l}\text { Managing } \\
\text { capabilitis }\end{array}$ & \\
\hline Model 1 & Low/Medium-low & 0.928 & $\mathrm{~F}_{9}$ & $\begin{array}{c}=-0.099 * \mathrm{~F}_{1} \\
(-0.521)\end{array}$ & $\begin{array}{c}0.178 * \mathrm{~F}_{4} \\
(2.964 @)\end{array}$ & + & $\begin{array}{c}0.214 * F_{8} \\
(2.705 @)\end{array}$ & $\begin{array}{c}+0.137 * \mathrm{~F}_{2} \\
(1.044)\end{array}$ & $+\mathrm{D}_{9}$ \\
\hline Model 1 & Medium-high/High & 0.912 & $\mathrm{~F}_{9}$ & $\begin{array}{c}=0.348 * \mathrm{~F}_{1} \\
(1.875)\end{array}$ & $\begin{array}{c}0.342 * \mathbf{F}_{4} \\
(2.626 @)\end{array}$ & - & $\begin{array}{l}0.349 * F_{8} \\
(-1.826)\end{array}$ & $\begin{array}{c}+\quad 0.002 * \mathrm{~F}_{2} \\
(0.009)\end{array}$ & $+\mathrm{D}_{9}$ \\
\hline Model 2 & Low/Medium-low & 0.927 & $\mathrm{~F}_{9}$ & $\begin{aligned}= & 0.076 * \mathrm{~F}_{1} \\
& (0.842)\end{aligned}$ & $\begin{array}{r}\quad 0.198 * \mathrm{~F}_{4} \\
(3.632 @)\end{array}$ & + & $\begin{array}{c}0.244 * F_{8} \\
(3.520 @)\end{array}$ & & $+\mathrm{D}_{9}$ \\
\hline Model 2 & Medium-high/High & 0.913 & $\mathrm{~F}_{9}$ & $\begin{array}{r}=0.350 * \mathrm{~F}_{1} \\
(2.873 @)\end{array}$ & $\begin{array}{c}\quad 0.342 * \mathbf{F}_{4} \\
(3.364 @)\end{array}$ & - & $\begin{array}{l}0.348 * \mathrm{~F}_{8} \\
(-2.502 @)\end{array}$ & & $+\mathrm{D}_{9}$ \\
\hline Model 3 & Low/Medium-low & 0.938 & $\mathrm{~F}_{9}$ & $=$ & $\begin{array}{l}0.163 * \mathrm{~F}_{4} \\
(2.642 @)\end{array}$ & + & $\begin{array}{c}0.206 * F_{8} \\
(2.672 @)\end{array}$ & $\begin{array}{c}+\quad 0.110 * \mathrm{~F}_{2} \\
(1.656)\end{array}$ & $+\mathrm{D}_{9}$ \\
\hline Model 3 & Medium-high/High & 0.934 & $\mathrm{~F}_{9}$ & $=$ & $\begin{array}{c}0.353 * \mathbf{F}_{4} \\
(2.700 @)\end{array}$ & - & $\begin{array}{l}0.202 * \mathrm{~F}_{8} \\
(-1.197)\end{array}$ & $\begin{array}{c}+0.147 * \mathrm{~F}_{2} \\
(1.042)\end{array}$ & $+\mathrm{D}_{9}$ \\
\hline Model 4 & Low/Medium-low & 0.937 & $\mathrm{~F}_{9}$ & $=$ & $\begin{array}{c}0.206 * \mathrm{~F}_{4} \\
(4.136 @)\end{array}$ & + & $\begin{array}{c}0.276 * F_{8} \\
(4.493 @)\end{array}$ & & $+\mathrm{D}_{9}$ \\
\hline Model 4 & Medium-high/High & 0.933 & $\mathrm{~F}_{9}$ & $=$ & $\begin{array}{c}0.417 * F_{4} \\
(4.605 @)\end{array}$ & - & $\begin{array}{l}0.063 * F_{8} \\
(-0.601)\end{array}$ & & $+\mathrm{D}_{9}$ \\
\hline Model 5 & Low/Medium-low & 0.943 & $\mathrm{~F}_{9}$ & $=$ & $\begin{array}{c}0.202 * F_{4} \\
(3.347 @)\end{array}$ & & & $\begin{array}{r}+\quad 0.181 * \mathrm{~F}_{2} \\
(3.622 @)\end{array}$ & $+\mathrm{D}_{9}$ \\
\hline Model 5 & Medium-high/High & 0.949 & $\mathrm{~F}_{9}$ & $=$ & $\begin{array}{c}0.331 * F_{4} \\
(2.678 @)\end{array}$ & & & $\begin{array}{c}+0.087 * \mathrm{~F}_{2} \\
(0.876)\end{array}$ & $+\mathrm{D}_{9}$ \\
\hline Model 6 & Low/Medium-low & 0.939 & $\mathrm{~F}_{9}$ & $=$ & $\begin{array}{c}0.309 * \mathbf{F}_{4} \\
(5.862 @)\end{array}$ & & & & $+\mathrm{D}_{9}$ \\
\hline Model 6 & Medium-high/High & 0.948 & $\mathrm{~F}_{9}$ & $=$ & $\begin{array}{c}0.393 * F_{4} \\
(4.633 @)\end{array}$ & & & & $+\mathrm{D}_{9}$ \\
\hline Model 7 & Low/Medium-low & 0.945 & $\mathrm{~F}_{9}$ & $=$ & $\begin{array}{c}0.256 * \mathbf{F}_{4} \\
(5.818 @)\end{array}$ & & & & $+\mathrm{D}_{9}$ \\
\hline Model 7 & Medium-high/High & 0.948 & $\mathrm{~F}_{9}$ & $=$ & $\begin{array}{c}0.295 * F_{4} \\
(4.766 @)\end{array}$ & & & & $+\mathrm{D}_{9}$ \\
\hline
\end{tabular}

Note. The highest value for each case is in bold letters.

Again, for the rest of the presented models (5,6 and 7), a clear feature is the coincidence in the importance of the innovative capabilities over competitiveness, no matter the company size, especially when the direct (positive) effect from management capabilities is taken out. 
As it is shown in Table 6, the positive effect from innovation capabilities is clearer in the case of mid-upper and upper OECD technological groups. This confirms $\mathrm{H}_{3}$. For the case of companies with higher technological level, the most determinant factor is the innovation capabilities. On the contrary, for the lower and mid-lower group, it is the quality capabilities. In fact, we observe that the effect from quality turns negative in the case of the upper and mid-upper group, and in some cases, with a statistically significant level.

For a more complete and satisfactory explanation of this phenomenon, it seems necessary to perform an analysis considering the technological issue with greater detail, and considering more specific factors than the ones included here. There is empirical evidence showing that the use of quality management practices does not exert a direct effect on innovative performance. On the contrary, it has been obtained that they do show a positive relationship if it is moderated by factors such as the capacity for R\&D management or the organizational learning (Camisón, Puig, \& Flores, 2009).

Table 7

Results From the Structural Model According to the Subcontractor Character

\begin{tabular}{|c|c|c|c|c|c|c|c|c|c|c|c|c|c|}
\hline Model & $\begin{array}{l}\text { Subcontr. } \\
\text { character }\end{array}$ & NFI & Comp. & & $\begin{array}{l}\text { Marketing } \\
\text { capabilities }\end{array}$ & & $\begin{array}{l}\text { Innovation } \\
\text { capabilities }\end{array}$ & & $\begin{array}{l}\text { Quality } \\
\text { capabilities }\end{array}$ & & $\begin{array}{l}\text { Managing } \\
\text { capabilities }\end{array}$ & & \\
\hline Model 1 & Subcontr. & 0.927 & $\mathrm{~F}_{9}$ & $=$ & $\begin{array}{l}0.065^{*} \mathrm{~F}_{1} \\
(0.261)\end{array}$ & + & $\begin{array}{l}0.150 * \mathrm{~F}_{4} \\
(1.879)\end{array}$ & + & $\begin{array}{l}0.187 * F_{8} \\
(1.768)\end{array}$ & + & $\begin{array}{l}0.053 * F_{2} \\
(0.294)\end{array}$ & + & $\mathrm{D}_{9}$ \\
\hline Model 1 & $\begin{array}{l}\text { Non } \\
\text { subcontr. }\end{array}$ & 0.918 & $\mathrm{~F}_{9}$ & $=$ & $\begin{array}{l}0.015 * \mathrm{~F}_{1} \\
(0.091)\end{array}$ & + & $\begin{array}{l}0.309 * F_{4} \\
(3.966 @\end{array}$ & + & $\begin{array}{l}0.064 * \mathrm{~F}_{8} \\
(0.590)\end{array}$ & + & $\begin{array}{l}0.113^{*} \mathrm{~F}_{2} \\
(0.793)\end{array}$ & + & $\mathrm{D}_{9}$ \\
\hline Model 2 & Subcontr. & 0.927 & $\mathrm{~F}_{9}$ & $=$ & $\begin{array}{l}0.133 * \mathrm{~F}_{1} \\
(1.105)\end{array}$ & + & $\begin{array}{c}0.158 * \mathrm{~F}_{4} \\
(2.264 @)\end{array}$ & + & $\begin{array}{c}0.199 * F_{8} \\
(2.145 @)\end{array}$ & & & + & $\mathrm{D}_{9}$ \\
\hline Model 2 & $\begin{array}{l}\text { Non } \\
\text { subcontr. }\end{array}$ & 0.918 & $\mathrm{~F}_{9}$ & $=$ & $\begin{array}{l}0.128 * \mathrm{~F}_{1} \\
(1.392)\end{array}$ & + & $\begin{array}{c}0.334 * F_{4} \\
(4.716 @)\end{array}$ & + & $\begin{array}{l}0.098 * \mathrm{~F}_{8} \\
(1.180)\end{array}$ & & & + & $\mathrm{D}_{9}$ \\
\hline Model 3 & Subcontr. & 0.942 & $\mathrm{~F}_{9}$ & $=$ & & & $\begin{array}{l}0.145^{*} \mathrm{~F}_{4} \\
(1.802)\end{array}$ & + & $\begin{array}{l}0.188 * F_{8} \\
(1.843)\end{array}$ & + & $\begin{array}{l}0.091 * \mathrm{~F}_{2} \\
(1.014)\end{array}$ & + & $\mathrm{D}_{9}$ \\
\hline Model 3 & $\begin{array}{l}\text { Non } \\
\text { subcontr. }\end{array}$ & 0.930 & $\mathrm{~F}_{9}$ & $=$ & & & $\begin{array}{c}0.297 * F_{4} \\
(3.703 @)\end{array}$ & + & $\begin{array}{l}0.101 * \mathrm{~F}_{8} \\
(1.001)\end{array}$ & + & $\begin{array}{l}0.114 * \mathrm{~F}_{2} \\
(1.366)\end{array}$ & + & $\mathrm{D}_{9}$ \\
\hline Model 4 & Subcontr. & 0.941 & $\mathrm{~F}_{9}$ & $=$ & & & $\begin{array}{c}0.180 * \mathrm{~F}_{4} \\
(2.889 @)\end{array}$ & + & $\begin{array}{l}0.254 * \mathbf{F}_{8} \\
(3.218 @\end{array}$ & & & + & $\mathrm{D}_{9}$ \\
\hline Model 4 & $\begin{array}{l}\text { Non } \\
\text { subcontr. }\end{array}$ & 0.929 & $\mathrm{~F}_{9}$ & $=$ & & & $\begin{array}{c}0.335^{*} \mathbf{F}_{4} \\
(5.171 @)\end{array}$ & + & $\begin{array}{c}0.196 * \mathrm{~F}_{8} \\
(2.736 @)\end{array}$ & & & + & $\mathrm{D}_{9}$ \\
\hline Model 5 & Subcontr. & 0.950 & $\mathrm{~F}_{9}$ & $=$ & & & $\begin{array}{c}0.190 * F_{4} \\
(2.495 @)\end{array}$ & & & + & $\begin{array}{c}0.157 * \mathrm{~F}_{2} \\
(2.400 @)\end{array}$ & + & $\mathrm{D}_{9}$ \\
\hline Model 5 & $\begin{array}{l}\text { Non } \\
\text { subcontr. }\end{array}$ & 0.945 & $\mathrm{~F}_{9}$ & $=$ & & & $\begin{array}{c}0.317^{*} F_{4} \\
(4.054 @)\end{array}$ & & & + & $\begin{array}{c}0.147 * \mathrm{~F}_{2} \\
(2.361 @)\end{array}$ & + & $\mathrm{D}_{9}$ \\
\hline Model 6 & Subcontr. & 0.947 & $\mathrm{~F}_{9}$ & $=$ & & & $\begin{array}{c}0.291 * F_{4} \\
(4.654 @)\end{array}$ & & & & & + & $\mathrm{D}_{9}$ \\
\hline Model 6 & $\begin{array}{l}\text { Non } \\
\text { subcontr. }\end{array}$ & 0.942 & $\mathrm{~F}_{9}$ & $=$ & & & $\begin{array}{c}0.402 * F_{4} \\
(5.924 @)\end{array}$ & & & & & + & $\mathrm{D}_{9}$ \\
\hline Model 7 & Subcontr. & 0.950 & $\mathrm{~F}_{9}$ & $=$ & & & $\begin{array}{c}0.246 * F_{4} \\
(4.661 @)\end{array}$ & & & & & + & $\mathrm{D}_{9}$ \\
\hline Model 7 & $\begin{array}{l}\text { Non } \\
\text { subcontr. }\end{array}$ & 0.943 & $\mathrm{~F}_{9}$ & $=$ & & & $\begin{array}{c}0.307 * F_{4} \\
(6.041 @)\end{array}$ & & & & & + & $\mathrm{D}_{9}$ \\
\hline
\end{tabular}

Note. The highest value for each case is in bold letters. 
On the other hand, previous studies point to the idea that both quality and innovation management are processes that show a very different pattern depending on the industry. In the biotech industry, it is capital for any business to team up in networks, to the extreme that the less interconnected ones are more prone to fail (Powell et al., 1996). In particular, companies from this industry must possess the ability to outperform in the generation of scientific contributions and, at the same time, be efficient at the correct evaluation of what other companies are doing. Other studies have stressed on the importance of teaming up with partners in industries such as information technologies (Cloodt, Hagedoorm, \& Roijakkers, 2006).

Table 7 shows the greater effect that the innovation capabilities factor has on non-subcontractor companies, which confirms our hypothesis $\mathrm{H}_{4}$. For the case of subcontractor firms (i.e., those that produce under the specifications of a design given by other companies, with little or no capability to decide on it or on the technical features of the product), the fundamental factor for competitiveness is the quality capabilities, and this significant relationship dilutes in the case of non-subcontractor companies.

Therefore, we see in general that innovation capabilities seem as the most determinant factor for competitiveness among those companies that are of larger size, upper technological level and of non-subcontractor character, whereas the quality capabilities factor shows most determinant for competitiveness among companies that are smaller, of lower technological level and of a subcontractor character.

To summarize, these three analyzed control variables are related among themselves as it is shown in Table 8 .

Table 8

Contingency Tables Among the Company Size, Technological Level and Subcontractor Character

\begin{tabular}{|c|c|c|c|}
\hline \multirow{2}{*}{ Company size } & \multicolumn{2}{|c|}{ Technological level } & \multirow{2}{*}{-Total } \\
\hline & Low/Medium-low & Medium-high/High & \\
\hline Smaller or equal to median & 325 & 112 & 437 \\
\hline Bigger than median & 261 & 163 & 424 \\
\hline Total & 586 & 275 & 861 \\
\hline$\chi^{2}=16.255$ & sig. $=0.000$ & & \\
\hline Gamma $=0.289$ & sig. $=0.000$ & & \\
\hline \multirow{2}{*}{ Company size } & \multicolumn{2}{|c|}{ Subcontractor character } & \multirow{2}{*}{ Total } \\
\hline & Yes & No & \\
\hline Smaller or equal to median & 250 & 180 & 430 \\
\hline Bigger than median & 175 & 238 & 413 \\
\hline Total & 425 & 418 & 843 \\
\hline$\chi^{2}=20.949$ & sig. $=0.000$ & & \\
\hline Gamma $=0.308$ & sig. $=0.000$ & & \\
\hline \multirow{2}{*}{ Technological level } & \multicolumn{2}{|c|}{ Subcontractor character } & \multirow{2}{*}{ Total } \\
\hline & Yes & No & \\
\hline Low/Medium-low & 330 & 246 & 576 \\
\hline Medium-high/High & 95 & 172 & 267 \\
\hline Total & 425 & 418 & 843 \\
\hline$\chi^{2}=34.400$ & sig. $=0.000$ & & \\
\hline Gamma $=0.417$ & sig. $=0.000$ & & \\
\hline
\end{tabular}

It can be seen that for the three combinations, the Pearson's Chi-square statistic presents a significance of less than 0.05 . Therefore, the hypothesis of factor independence is rejected in all the cases. Also, the Goodman and 
Kruskal's Gamma coefficients show that strength of the relationship is higher between technological level and subcontractor character: companies with a lower technological level tend to be subcontractors, whereas those with a higher technological level do not. Secondly, between company size and subcontractor character: smaller companies tend to be subcontractors whereas the larger ones do not. Finally, the relationship between size and technological level: smaller companies tend to be of a lower technological level, and the larger ones of a higher technological level.

\section{Conclusions}

Companies with superior innovation capabilities are characterized by the frequent addition of incremental product innovations, their capacity to develop and market radically innovative products, a continuous investment on the production and commercial processes, and for a well focused and significant investment on their employees' training and development.

Specifically, among the variables that had been cited by managers as most important, the variable measuring its capability to develop and market radically innovative products is the one which most intensely reflects the innovative capabilities of the company, followed by the one measuring their capability for the introduction of incremental product innovations, the one measuring the capability to innovate on production and commercial processes, the one evaluating their capability to innovate in management and administration, and lastly, the one measuring the investment in training and development of their personnel.

Companies with superior innovative capabilities reach a higher performance, evidenced in a greater level of growth in sales and greater profitability compared with reference competitors.

In any case, the relationship between innovation capabilities and competitiveness is moderated by the company size, technological level of the sector to which it belongs, and its subcontractor character. Thus, the effect of innovation on competitiveness is of a higher degree among the companies of a bigger size, higher technological level and those which do not show a subcontractor character, compared to those companies of a smaller size, lower technological level and subcontractor character.

In fact, for those companies of the first group, the innovation capabilities factor is, among all the internal factors analysed, the one with the greatest explaining power, whereas for the case of the second group of companies, the most determinant internal factor is their quality capability, although the innovative capabilities are also important.

On the other hand, we observe that there is a relationship among the three control variables analysed, such as that smaller enterprises tend to show a lower technological profile and a subcontractor character, whereas bigger companies tend to show a higher technological level and not to be subcontractor companies.

\section{Limitations and Future Lines of Research}

A study on the sources of competitiveness always confronts the decision about which sources to include and which not. A comprehensive study would be impossible, especially for the case of an empirical study like ours. Therefore, the main limitation should be considered liable to the essence of the very research, including only the management, innovation, quality and marketing capabilities. Also, the characterizing of the analysed factors has been limited to a set of items per factor (at an initial stage, just three to five per factor), due to restrictions imposed by the use of quantitative techniques of analysis based on survey data. 
As regards the use of a qualitative exploratory method, which consisted on in-depth interviews to managers, it allowed us to design scales that were simple and of easy understanding, aiming to be applicable to a large sample of companies of great diversity in terms of size and type of industry. We are aware that by proceeding in this manner, and not from the use of previously tried and validated scales in the extant literature may be criticisable. However, we can assure that the used items are those that described best, in the opinion of the interviewed managers, each of the factors that were studied for the particular case of the Basque industry.

Also, although the empirical study here performed included up to seven different models to compare, there were no alternative model considering the (supposed) causal relations among the three studied capabilities of marketing, innovation and quality, times the different alternatives coming from changing the direction of the causal relation. In future analyses we will introduce new relations among these, as well as new factors. In this manner, we could generate hierarchical models of superior value, providing more support to the hypotheses here tested, together with new ones. This could also allow us to perform a more exhaustive analysis of the relationship between innovation and quality capabilities, something that seems necessary, to the light of the results here obtained.

In the same manner, for a future we devise the study of the moderating effect from other variables, such as the company internationalisation or its legal form, on the effect between innovation capabilities and performance.

Last but not least, the study relied on cross-sectional data, but it would have been preferable a long-sectional basis in order to study the time effect of the main causal relation, especially between innovation and quality capabilities and performance.

\section{References}

Acquaah, M. (2003). Corporate management, industry competition and the sustainability of firm abnormal profitability. Journal of Management \& Governance, 7(1), 57-85.

Acs, Z. J., \& Audretsch, D. B. (1990). Innovation and small firms. MIT Press: Cambridge, MA.

Aguirre, M. S., Charterina, J., Idigoras, I., Martinez, R., \& Matey, J. (2006). Estudio de las estrategias de competitividad de las empresas industriales vascas: fase cuantitativa. Bilbao: Sociedad para la Promoción y Reconversión Industrial (SPRI) and Instituto de Economía Aplicada a la Empresa de la UPV/EHU (IEAE).

Amit, R., \& Schoemaker, P. J. H. (1993). Strategic assets and organizational rent. Strategic Management Journal, 14(1), 33-46.

Barney, J. B. (1991). Firm resources and sustained competitive advantage. Journal of Management, 17(1), 99-120.

Bentler, P. M. (1990). Comparative fit indexes in structural models. Psychological Bulletin, 107(2), 238-246.

Bentler, P. M. (1992). On the fit of models to covariances and methodology to the Bulletin. Psychological Bulletin, 112(3), 400-404.

Bentler, P. M., \& Bonett, D. G. (1980). Significance tests and goodness of fit in the analysis of covariance structures. Psychological Bulletin, 88(3), 588-606.

Browne, M. W., \& Cudeck, R. (1993). Alternative ways of assessing model fit. In K. A. Bollen \& J. S. Long (Eds.), Testing Structural Equation Models (pp. 136-162). Newbury Park, CA: Sage.

Cainelli, G., Evangelista, R., \& Savona, M. (2006). Innovation and economic performance in services: A firm-level analysis. Cambridge Journal of Economics, 30(3), 435-458.

Calvo, A. R., \& López, V. A. (2003). Modelo RBV y rendimiento empresarial: Análisis discriminante en PYMEs gallegas. Boletín de estudios económicos, 59(180), 503-521.

Camisón, C., Puig, A., \& Flores, B. (2009). Efectos de la gestión de la calidad sobre el desempeño innovador: El papel mediador de las capacidades dinámicas de aprendizaje e innovación. XXIII Congreso Anual ADEDEM, Administrando en entornos inciertos/Managing in Uncertain Environment, Proceedings (Sevilla, July 3, 4 and 5).

Carmeli, A. (2001). High-and low-performance firms: Do they have different profiles of perceived core intangible resources and business environment? Technovation, 21(10), 661-671.

Carmeli, A., \& Tishler, A. (2006). The relative importance of the top management team's managerial skills. International Journal of Manpower, 27(1), 9-36. 
Castanias, R. P., \& Helfat, C. E. (1991). Managerial resources and rents. Journal of Management, 17(1), 155-171.

Castanias, R. P., \& Helfat, C. E. (2001). The managerial rents model: Theory and empirical analysis. Journal of Management, 27(6), 661-678.

Cefis, E., \& Marsili, O. (2005). A matter of life and death: Innovation and firm survival. Industrial and Corporate Change, 14(6), 1167-1192.

Clark, B., \& Griliches, Z. (1984). Productivity and R\&D at the firm level in French manufacturing. In Z. Griliches (Ed.), $R \& D$, Patents, and Productivity (pp. 393-416). Chicago: University of Chicago Press.

Claver, E., Molina, J. F, Quer, D., \& Tarí, J. J. (2005). Influencia de la definición industrial sobre la importancia relativa de los efectos empresa e industria. Revista Europea de Dirección y Economía de la Empresa, 14(1), 45-60.

Climent Serrano, S. (2003, September). Los costes de Calidad como estrategia empresarial: Evidencia empírica en la comunidad valenciana (Doctoral Thesis, Universidad de Valencia).

Cloodt, M., Hagedoorm, J., \& Roijakkers, N. (2006). Trends and patterns in interfirm R\&D networks in the global computer industry: An analysis of major developments, 1970-1999. Business History Review, 80(4), 725-748.

Cohen, W. M., \& Levinthal, D. A. (1990). Absorptive capacity. A new perspective on learning and innovation. Administrative Science Quarterly, 35(1), 128-152.

Cohen, W., \& Klepper, S. (1996). Firm size and the nature of innovation within industries: The case of product and process R\&D. Review of Economics and Statistics, 78(2), 232-243.

Creswell, J. W. (1995). Research design: Qualitative, quantitative, and mixed methods approaches. Thousand Oaks, California: Sage Publications.

Day, G. S. (1994). The capabilities of market-driven organizations. Journal of Marketing, 58(4), 37-52.

De Carolis, D. M. (2003). Competencies and imitability in the pharmaceutical industry: An analysis of their relationship with firm performance. Journal of Management, 29(1), 27-50.

Denzin, N. (1970). Strategies of multiple triangulation. In N. Denzin (Ed.), The Research Act (pp. 297-331). New York: McGraw Hill.

Dutta, S., Narasimhan, O., \& Rajiv, S. (1999). Success in high-technology markets: Is marketing capability critical. Marketing Science, 18(4), 547-568.

Eustat. (2008). Instituto Vasco de Estadística (www.eustat.es)/Banco de datos/Series estadísticas por temas/Industria y Construcción/Industria/Macromagnitudes por principales agregados, territorio y sector (A84) (miles de euros) Base 2005.

Fahy, J., \& Smithee, A. (1999). Strategic marketing and the resource based view of the firm. Academy of Marketing Science Review, 10, 1-20.

Fernández, E., Montes, J. M., \& Vázquez, C. J. (1999). Las fuentes de creación de valor en la empresa. Boletín de estudios económicos, 54(166), 95-120.

Forrest, J. E. (1991). Models of the process of technological innovation. Technology Analysis and Strategic Management, 3(4), 439-452.

Galán. J. L., \& Vecino. J. (1997). Las fuentes de rentabilidad de las empresas. Revista Europea de Dirección y Economía de la Empresa, 6(1), 21-36.

Galende, J. (2006). Analysis of technological innovation from business economics and management. Technovation, 26(3), $300-311$.

Galende, J., \& Suárez, I. (1998). Los factores determinantes de las inversiones empresariales en I + D. Economía Industrial, 319 , 63-76.

Galende, J., \& Suárez, I. (1999). A resource-based analysis of the factors determining a firm's R\&D activities. Research Policy, 28, 891-905.

Grant, R. M. (1991). The resource based theory of competitive advantage: Implications for strategy formulation. California Management Review, 33(3), 114-135.

Griliches, Z. (1979). Issues in assessing the contribution of research and development to productivity growth. Bell Journal of Economics, 10(1), 92-116.

Griliches, Z. (1980). Returns to research and development expenditures in the private sector. In J. Kendrick \& B. Vaccara (Eds.), New Developments in Productivity Measurement and Analysis (pp. 339-374). Chicago: University of Chicago Press.

Griliches, Z., \& Mairesse, J. (1984). Productivity and R\&D at the firm level. In Z. Griliches (Ed.), R\&D, Patents, and Productivity (pp. 339-374). Chicago: University of Chicago Press.

Hall, R. (1992). The strategic analysis of intangible resources. Strategic Management Journal, 13(2), 135-144.

Hall, R. (1993). A framework linking intangible resources and capabilities to sustainable competitive advantage. Strategic Management Journal, 14(8), 607-618. 
Hooley, G. J., Broderick, A., \& Möller, K. (1998). Competitive positioning and the resource-based view of the firm. Journal of Strategic Marketing, 6(2), 97-115.

Hooley, G. J., Greenley, G. E., Cadogan, J. W., \& Fahy, J. (2005). The performance impact of marketing resources. Journal of Business Research, 58(1), 18-27.

Hooley, G. J., Fahy, J., Cox, T., Beracs, J., Fonfara, K., \& Snoj, B. (1999). Marketing capabilities and firm performance: A hierarchical model. Journal of Market Focused Management, 4(3), 259-278.

Hu, L. T., \& Bentler, P. M. (1999). Cutoff criteria for fit indexes in covariance structure analysis: Conventional criteria versus new alternatives. Structural Equation Modeling, 6(1), 1-55.

Huergo, E., \& Jaumandreu, J. (2004). How does probability of innovation change with firm age? Small Business Economics, 22(3/4), 193-207.

Human, S. E., \& Provan, K. (1997). An emergent theory of structure and outcomes in small-firm strategic manufacturing networks. Academy of Management Journal, 40(2), 368-402.

Hunt, S. D., \& Morgan, R. M. (1995). The comparative advantage theory of competition. Journal of Marketing, 59(2), 1-15.

Jaworski, B. J., \& Kohli, A. K. (1993). Market orientation: antecedents and consequences. Journal of Marketing, 57(3), 53-60.

Johannessen, J. A., Olsen, B., \& Lumpkin, G. T. (2001). Innovation as newness: What is new, how new, and new to whom? European Journal of Innovation Management, 4(1), 20-31.

Juran, J. M. (1990). Juran y el liderazgo para la calidad. Un manual para directivos. Madrid: Diaz de Santos.

Kafouros, M. I. (2008). Industrial innovation and firm performance: The impact of scientific knowledge on multinational corporations. Cheltenham, UK: Edward Elgar.

Kline, R. B. (2005). Principles and practice of structural equation modeling. New York: The Guildford Press.

Kor, Y. Y. (2003). Experience-based top management team competence and sustained growth. Organization Science, 14(6), 707-719.

Lado, A. A., \& Wilson, M. C. (1994). Human resource systems and sustained competitive advantage: A competency-based perspective. Journal of Management, 19(4), 699-727.

Lee, C. Y. (2004). Perception and development of total quality management in small manufactures: An exploratory study in China. Journal of Small Business Management, 42(1), 102-115.

Leonard-Barton, D. (1992). Core capabilities and core rigidities: A paradox in managing new product development. Strategic Management Journal, 13(S1), 111-125.

Lerner, M., \& Almor, T. (2002). Relationships among strategic capabilities and the performance of women-owned small ventures. Journal of Small Business Management, 40(2), 109-125.

Lichtenberg, F., \& Siegel, D. (1991). The impact of R\&D investment on productivity-new evidence using linked R\&D-LRD data. Economic Inquiry, 29(2), 203-229.

MacCallum, R. C., \& Austin, J. T. (2000). Applications of structural equation modeling in psychological research. Annual Review of Psychology, 51, 201-236.

MacCallum, R. C., Wegener, D. T., Unchino, B. N., \& Fabrigar, L. R. (1993). The problem of equivalent models in applications of covariance structure analysis. Psychological Bulletin, 114(1), 185-199.

Mahoney, J. T. (1995). The management of resources and the resource of management. Journal of Business Research, 33(2), 91-101.

Mahoney, J. T., \& Pandian, J. R. (1992). The resource-based view within the conversation of strategic management. Strategic Management Journal, 13(5), 363-380.

Malhotra, M. K., \& Grover, V. (1998). An assessment of survey research in production and operations management: From constructs to theory. Journal of Operations Management, 16(4), 407-425.

Mansfield, E. (1968). The economics of technological change. New York: Norton.

Marsh, H. W., \& Hau, K. T. (1999). Confirmatory factor analysis: Strategies for small sample sizes. In R. H. Hoyle (Ed.), Statistical Strategies For Small Sample Research (pp. 252-284). Thousand Oaks, CA: Sage.

Martínez Santa María, R. (2009, September). Factores internos de competitividad y desempeño de las empresas industriales vascas: Un modelo causal (Doctoral Thesis, Universidad del País Vasco-UPV/EHU).

Martínez-Ros, E., \& Salas, V. (1999). Innovación y salarios en la manufactura española. Papeles de Economía Española, 81, 92-103.

Mauri, A., \& Michaels, M. (1998). Firm and industry effects within strategic management: An empirical examination. Strategic Management Journal, 19(3), 211-219. 
Milfelner, B., Gabrijan, V., \& Snoj, B. (2008). Can marketing resources contribute to company performance? Organizacija, 41(1), 3-13.

O'Regan, N., \& Ghobadian, A. (2004). The importance of capabilities for strategic direction and performance. Management Decision, 42(2), 292-312.

OECD \& EUROSTAT. (2005). Manual de Oslo. Guía para la recogida e interpretación de datos sobre innovación (3rd ed.). París: OECD y EUROSTAT.

Parasuraman, A., Zeithaml, V., \& Berry, L. (1985). A conceptual model of service quality and its implications for future research. Journal of Marketing, 49(4), 41-50.

Pavitt, K. (2003). The process of innovation (SPRU electronic working paper No. 89). The Freeman Centre, University of Sussex. Brighton, UK.

Perdomo-Ortiz, J., González-Benito, J., \& Galende, J. (2006). Total quality management as a forerunner of business innovation capability. Technovation, 26(10), 1170-1185.

Peteraf, M. A. (1993). The cornerstones of competitive advantage: A resource based-view. Strategic Management Journal, 14(3), 179-191.

Piore, M. J., \& Sabel, C. F. (1984). The second industrial divide: Possibilities for prosperity. Basic Books: New York.

Powell, T. C. (1995). Total quality management as competitive advantage: A review and empirical study. Strategic Management Journal, 16(4), 15-38.

Powell, W. W., White, D. R., Koput, K. W., \& Owen-Smith, J. (2005, January). Network dynamics and field evolution: The growth of interorganizational collaboration in the life sciences. The American Journal of Sociology, 110(4), 1132-1206.

Prahalad, C. K., \& Hamel, G. (1990). The core competences of the corporation. Harvard Business Review, 68(mayo-junio), 79-91.

Reed, R., \& DeFillippi, R. J. (1990). Causal ambiguity, barriers to imitation, and sustainable competitive advantage. Academy of Management Review, 15(1), 88-102.

Roquebert, J., Phillips, R., \& Westfall, P. A. (1996). Markets versus management: What drives profitability? Strategic Management Journal, 17(8), 653-666.

Rothwell, R. (1994). Towards the fifth-generation innovation process. International Marketing Review, 11(1), 7-31.

Rubio, A., \& Aragón, A. (2008). Recursos estratégicos en las PYMEs. Revista Europea de Dirección y Economía de la Empresa, 17(1), 103-126.

Rumelt, R. P. (1991). How much does industry matter? Strategic Management Journal, 12(3), 167-185.

Selznick, P. (1957). Leadership in administration: A social interpretation. New York: Harper \& Row.

Spillan, J., \& Ziemnowicz, C. (2003). Strategic management in small retail businesses. The case of Guatemala. International Small Business Journal, 21(4), 461-478.

Srivastava, R. K., Fahey, L., \& Christensen, H. K. (2001). The resource-based view and marketing: The role of marked-based assets in gaining competitive advantage. Journal of Management, 27(6), 777-802.

Steiger, J. H., \& Lind, J. C. (1980). Statistically based tests for the number of common factors. Psychometric Society Annual Meeting. Iowa City, IA.

Steiger, J. H. (1990). Structural model evaluation and modification: An interval estimation approach. Multivariate Behavioral Research, 25(2), 173-180.

Teece, D. J. (1986). Profiting from technological innovation: Implications for integration, collaboration, licensing and public policy. Research Policy, 15(6), 285-305.

Tether, B. S. (2003). What is innovation? Approaches to distinguishing new products and processes from existing products and processes (CRIC working paper No. 12, University of Manchester).

Wang, J., \& Tsai, K. (2003). Productivity growth and R\&D expenditure in Taiwan's manufacturing firms. (NBER working paper No. 9724). National Bureau of Economic Research. Cambridge, MA.

Webster, F. E. (1992). The changing role of marketing in the corporation. Journal of Marketing, 56(4), 1-17.

Weigelt, K., \& Camerer, C. (1988). Reputation and corporate strategy: A review of recent theory and applications. Strategic Management Journal, 9(5), 443-454.

Wernerfelt, B. (1984). A resource-based view of the firm. Strategic Management Journal, 5(2), 171-180.

Winters, R., \& Stam, E. (2007). Beyond the firm: Innovation and networks of high-technology SMEs. In J. M. Arauzo-Carod \& M. C. Manjón-Antolín (Eds.), Entrepreneurship, Industrial Location and Economic Growth (Chapter 12). Cheltenham, UK: Edward Elgar.

Zollo, M., \& Winter, S. (2002). Deliberate learning and the evolution of dynamic capabilities. Organization Science, 13(3), 339-351. 